\title{
Membranous nephropathy: an update
}

Hernando Trujillo, Manuel Praga

Department of Nephrology, University Hospital 12 de Octubre, Madrid, Spain.

\section{ABSTRACT}

Great advances have been made in the pathophysiologic and therapeutic areas of membranous nephropathy in the last years. The description of autoantibodies directed against phospholipase A2 receptor in the glomerulus has confirmed the autoimmune nature of the disease and has changed our diagnostic, classification, and treatment strategies. Rituximab has emerged as a great tool in the therapeutic armamentarium of membranous nephropathy, but a one-size-fits-all approach is far from being the rule. Nowadays, an individualized therapeutic scheme based on clinical and serologic data appears to be the most appropriate method to manage patients with membranous nephropathy. We present a review of the most important aspects published in the literature regarding membranous nephropathy, with an emphasis on the most novel topics with the intention of updating clinicians involved in the management of this disease.

Keywords: glomerulonephritis, nephrotic syndrome, membranous nephropathy, phospholipase A2 receptor (PLA2R), autoimmune diseases.

\section{INTRODUCTION}

Membranous nephropathy (MN) is one of the most common causes of nephrotic syndrome in adults. ${ }^{1,2}$ It is a glomerular pattern of injury characterized by thickening of the glomerular basement membrane (GBM) because of deposition of subepithelial immune complexes. ${ }^{3}$ About $20 \%$ of the cases have a recognizable etiology (secondary MN), but in the majority of patients the pathogenesis remains incompletely defined (idiopathic membranous nephropathy). ${ }^{4}$ The identification in $2009^{5}$ of autoantibodies directed against the M-type phospholipase A2 receptor (PLA2R) located in the podocytes significantly changed the way we understand this entity. Most cases of membranous nephropathy $(70-85 \%)^{5,6}$ present antibodies against PLA2R, while 3-5\% ${ }^{7}$ present antibodies against thrombospondin type 1 domain containing 7A (THSD7A), and approximately $10 \%$ have negative serology (unknown pathophysiology). ${ }^{6}$ Thus, the term "idiopathic membranous nephropathy" has been gradually abandoned for the more appropriate term primary membranous nephropathy (PMN). Several treatment schemes for PMN have been proposed by different groups around the world, including chlorambucil plus steroids, ${ }^{8,9}$ cyclophosphamide plus steroids, ${ }^{10,11}$ calcineurin inhibitors, ${ }^{12}$ and rituximab. ${ }^{13,14}$ Prognosis of PMN is variable since $30 \%$ of the patients reach spontaneous remission (SR), a third are stable, and a third have persistent nephrotic syndrome and progressive deterioration of renal function. ${ }^{15,16}$

\section{EPIDEMIOLOGY}

The incidence of $\mathrm{MN}$ is estimated at about $5-10$ cases per million per year. In adults, MN represents between $20-40 \%$ of cases of nephrotic syndrome. ${ }^{1,2,6}$ It has a 2:1 male predominance with a mean age of 50-60 years. ${ }^{6}$ It is infrequent in the pediatric population and is most common in Caucasians followed by Asians, blacks and Hispanics. ${ }^{2,6}$

\section{PATHOGENESIS}

\section{Primary membranous nephropathy}

The search for the antigen or antigens responsible for the cases of the so-called idiopathic membranous nephropathy was unsuccessful for many years. Ronco et $\left.a\right|^{17}$ were the first group to demonstrate the decisive participation of a podocyte antigen (neutral endopeptidase) in an infantile case of $\mathrm{MN}$, although the cases of pediatric $\mathrm{MN}$ secondary to anti-neutral endopeptidase antibodies are very rare. More recently, Beck et $a l^{5}$ shown that the M-type phospholipase $\mathrm{A} 2$ receptor is a target antigen in primary membranous nephropathy in $70-85 \%$ of cases. Many other groups have confirmed this finding. ${ }^{2,3,6}$ Although PLA2R binds PLA2 under normal circumstances, its exact physiological role is unclear. Moreover, the trigger for antibody production is currently unknown. ${ }^{18}$ The antibodies formed against PLA2R (mainly IgG4) cross the glomerular capillaries and bind to the protein along the subepithelial side of the capillary wall forming the typical subepithelial deposits that are seen in $\mathrm{MN}^{5}$ In another subset of patients (3-5\%), other receptor located on the podocyte membrane (THSD7A) has been identified as a target autoantigen in $\mathrm{MN} .^{7}$ In some cases, the development of autoantibodies against THSD7A has been linked to malignant tumors. ${ }^{19,20}$ As in the case of PLA2R, it is not clear why antibodies develop. The remaining cases of PMN with negative serology ( 10-30\%) are probably caused by autoantibodies against as yet unidentified specific antigens. Besides the previously mentioned neutral endopeptidase, a possible pathogenic role of aldose reductase and manganese superoxide dismutase as podocyte antigens has been suggested. ${ }^{21}$ Moreover, immunization against bovine serum albumin has been proposed as a potential cause of $\mathrm{MN}$ in young children. ${ }^{22}$

The identification of anti-PLA2R has been an enormous breakthrough in the differential diagnosis of $\mathrm{MN}$, as the positivity of antiPLA2R is strongly indicative of a primary character. However, it should 
be noted that although rarely, patients with secondary MN may also have antibodies against PLA2R. ${ }^{23}$

The complement system also plays an important pathogenic role in $\mathrm{MN}$. Ronco et al ${ }^{17}$ observed that the neutral endopeptidase system is related to the activation of complement within immune deposits and the generation of membrane-attack complex ( $C 5 b-9)$. Once the antibodies are deposited in the capillary wall, the complement terminal factors alter the podocyte structure causing the onset of massive proteinuria. $^{24}$

Finally, some studies have reported a genetic basis associated with certain HLA alleles and genes encoding PLA2R that predispose to membranous nephropathy. ${ }^{25,26}$ These genetic variants could become useful biomarkers in the future to stratify the risk of developing the disease.

\section{Secondary membranous nephropathy}

Membranous nephropathy is a prototype of kidney disease caused by immune complexes. The most common causes of secondary MN include infections, cancer, autoimmune diseases, and drugs (Table 1). Implicated antigens are deposited between glomerular basement membrane and podocytes, and subsequently, be bound by circulating antibodies. ${ }^{3,22}$ Other explanation is that antigens may form circulating immune complexes that are subsequently trapped in glomerular capillaries or may dissociate and reform in the subepithelial space. ${ }^{3,27}$ The identification and treatment of the underlying cause leads in many cases to the resolution of the nephrotic syndrome.

Membranous nephropathy is the most frequent paraneoplastic glomerulopathy associated with solid tumors, ${ }^{28}$ but it is not always a linear relationship. Besides, in some cases, the association may be casual (two diseases at the same time) rather than causal. It has been reported that approximately $10 \%$ (up to $25 \%$ after age 60 years) of adult patients with $\mathrm{MN}$ had a malignancy at the time of renal biopsy

\section{Table 1}

Main causes of secondary membranous nephropathy. ${ }^{6,28,33}$ HIV: human immunodeficiency virus, ANCA: anti-neutrophil cytoplasmic autoantibody, NSAIDs: nonsteroidal anti- inflammatory drugs, TNFa: tumor necrosis factor alpha.

\begin{tabular}{c|l} 
Groups & \\
\hline Cancer & $\begin{array}{l}\text { Lung and bronchus, gastric, renal, prostatic, breast, colorectal, plasma } \\
\text { cell dyscrasias, non-Hodgkin lymphoma, chronic lymphocytic leukemia } \\
\text { mesothelioma, melanoma }\end{array}$ \\
Infections & $\begin{array}{l}\text { Hepatitis B, hepatitis C, HIV, syphilis, schistosomiasis, malaria, filariasis, } \\
\text { hydatid disease, leprosy }\end{array}$ \\
Autoimmune & $\begin{array}{l}\text { Systemic lupus erythematosus, Hashimoto's disease, Graves' disease, } \\
\text { diabetes, rheumatoid arthritis, Sjogren syndrome, dermatomyositis, } \\
\text { mixed connective tissue disease, ankylosing spondylitis, primary biliary } \\
\text { cirrhosis, bullous pemphigoid, retroperitoneal fibrosis, Guillain-Barré } \\
\text { syndrome, graft-versus-host disease, bone marrow and stem cell trans- } \\
\text { plantation, anti-GBM disease, IgA nephropathy, ANCA-associated vas- } \\
\text { culitis, renal transplantation, IgG4 disease }\end{array}$ \\
Drugs/toxins & $\begin{array}{l}\text { NSAIDs, penicillamine, gold, captopril, bucillamine agents, probenecid, } \\
\text { anti-TNFa, mercury, lithium, formaldehyde, hydrocarbons }\end{array}$ \\
\hline
\end{tabular}

or within a year thereafter. ${ }^{3,29}$ Solid tumors more frequently related to $\mathrm{MN}$ include lung and bronchus, gastric, renal, prostatic, breast, and colorectal. ${ }^{28}$

\section{CLINICAL MANIFESTATIONS}

In about $80 \%$ of cases, membranous nephropathy presents with a full nephrotic syndrome (proteinuria $>3.5 \mathrm{~g} / 24 \mathrm{~h}$, hypoalbuminemia, and dyslipidemia). ${ }^{30-32}$ As most patients present with the typical edema of nephrotic syndrome, early diagnosis is almost the rule. In the remaining cases (20-30\%), subnephrotic proteinuria may be the only sign of disease and therefore diagnosis can be significantly delayed due to the absence of symptoms. Proteinuria in MN is nonselective. Although microhematuria is relatively frequent ( $30 \%$ to $40 \%$ ), ${ }^{33}$ macroscopic hematuria is rare and suggests a different glomerular pathologic process, renal vein thrombosis or urologic neoplasms. Other clinical manifestations and complications are those of a nephrotic syndrome (edema, hyperlipidemia, and hypercoagulable state). Edema is usually less severe than in minimal change disease or primary focal segmental glomerulosclerosis, ${ }^{6}$ although there is great variability. Occasionally, renal vein thrombosis or pulmonary thromboembolism could be the initial clinical scenarios. The majority of cases ( 90\%) present normal renal function at presentation. ${ }^{33}$ Only $10-20 \%$ have hypertension at the time of diagnosis but up to $50 \%$ of cases present hypertension during the course of the disease, ${ }^{6}$ usually as a consequence of the development of renal insufficiency. In PMN, complement levels are normal and serologic markers (antinuclear antibodies, ANCA) are negative.

In cases with massive proteinuria and severe hypoalbuminemia, a progressive deterioration of renal function can be observed in the first months of clinical course. Moreover, as in any other cause of nephrotic syndrome, reversible episodes of acute kidney injury may be triggered as a consequence of excessive diuretic treatment or the use of renin-angiotensin-aldosterone system inhibitors. In the most severe cases of $\mathrm{MN}$, the presence of renal glycosuria and other manifestations of tubular injury can be found, ${ }^{34}$ probably related to direct tubular toxicity of massive proteinuria.

\section{Pathology}

Membranous nephropathy is characterized by a uniform and diffuse thickening of the glomerular basement membrane without associated cellular proliferation. The prominent GBM is a consequence of subepithelial immune complexes of IgG and complement along the outer surface of the capillary wall. ${ }^{16,33}$ By light microscopy, small deposits are visualized in the basement membrane as pinpoint lucencies on silver methenamine stain (Figure 1). Also, matrix reaction to the immune deposits results in subepithelial speculated extensions known as "spikes". 6,16,33 There are four pathologic stages of MN. In stage I, the only lesion on light microscopy consists of diffuse thickening of the GBM. Visualization of "spikes" and thickening of the GMB on light microscopy are the characteristics of stage II. Diffuse and extensive podocyte effacement and prominent subepithelial deposits on electron microscopy are observed in stage III. Finally, diffuse thickening of the GMB and deposits along the whole thickness of the GBM are seen in 


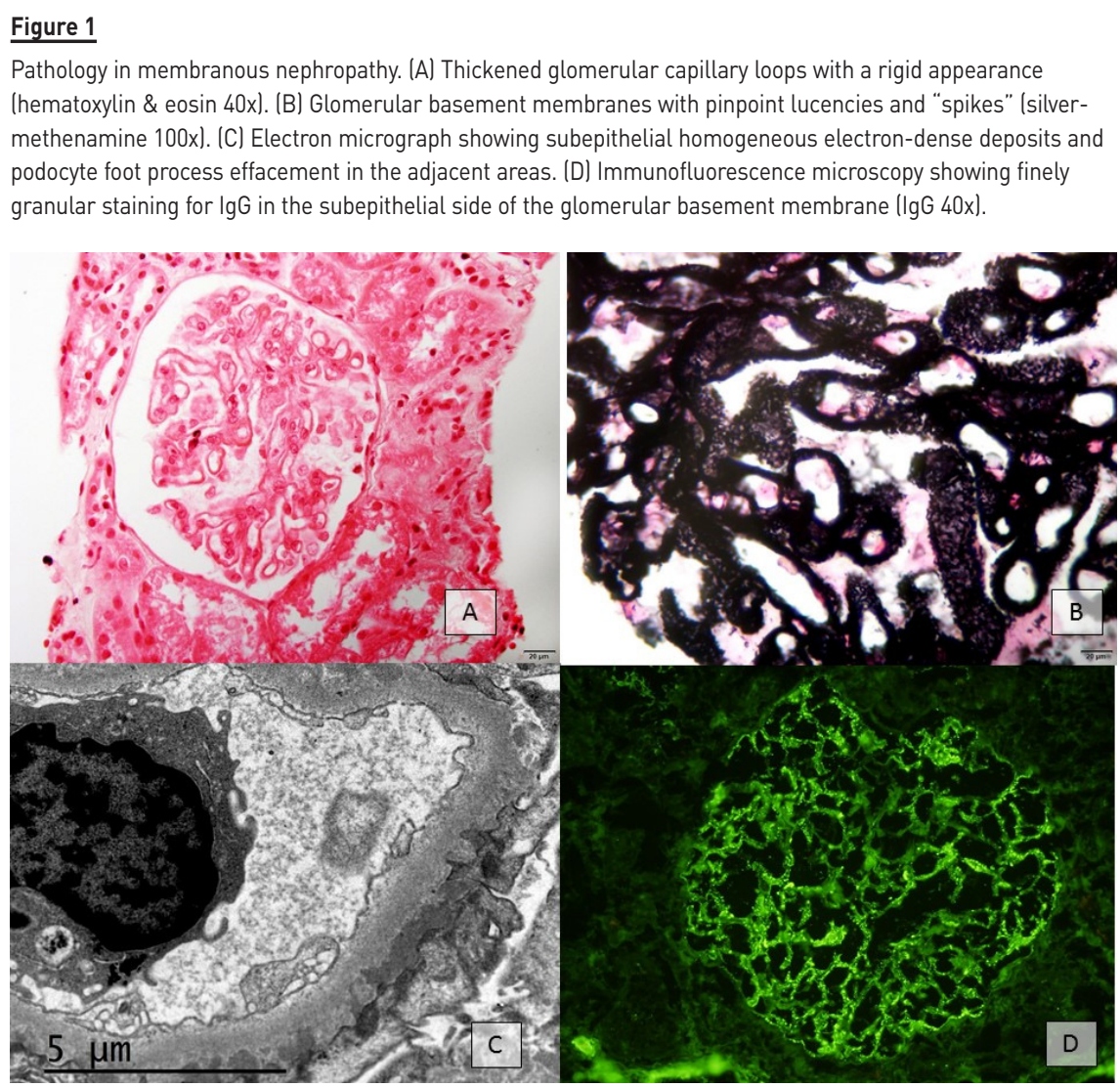

stage IV. It is important to point out that pathologic lesions and stages of MN have a poor correlation with prognosis and treatment response (with the exception of tubulointerstitial fibrosis). ${ }^{30,31}$

Immunofluorescence shows granular subepithelial deposits of IgG along the GBM. ${ }^{35}$ In about $50 \%$ of cases $\mathrm{C} 3$ is also positive. ${ }^{33}$ In cases of primary membranous nephropathy the predominant immunoglobulin is IgG4. If preponderant IgG1 or IgG3 is observed, a secondary cause should be suspected. Positivity for IgM, IgA, or C1q, should also prompt a careful search for secondary $\mathrm{MN} .{ }^{2}$ Another finding in favor of primary membranous nephropathy is the presence of PLA2R or THSD7A colocalized with $\operatorname{lgG} 4 .{ }^{3,6}$ It is important to remember that some patients may have negative serum anti-PLA2R with positive anti-PLA2R in renal tissue (seroconversion may occur during follow-up when the rate of production exceeds the buffering capacity of the kidney). ${ }^{3}$

In electron microscopy, the characteristic finding is the presence of homogeneous electron-dense deposits distributed along the subepithelial surface of glomeruli. If mesangial and subendothelial deposits are found, a secondary cause should be considered. The presence of cellular proliferation in glomeruli and endothelial tubuloreticular inclusions should raise the suspicion of membranous lupus nephritis. ${ }^{1}$

Some authors have proposed that a biopsy is not essential to make the diagnosis of PMN as antibodies against PLA2R are not detected in other renal diseases. However, renal biopsy remains the gold standard unless the patient has a specific contraindication for the procedure. In our opinion, renal biopsy can be obviated in patients with normal renal function and positive anti-PLA2R.

\section{OUTCOME}

Approximately half of the patients with non-nephrotic proteinuria have a favorable prognosis, with stable renal function and without hypertension. ${ }^{30,31}$ This subgroup of patients will have a high rate of spontaneous remission. However, up to $60 \%$ of these cases may develop a full nephrotic syndrome within 2 years of presentation. ${ }^{2}$

Among patients with nephrotic syndrome, three different types of clinical evolution can be identified: spontaneous remission (30$45 \%), 36,37$ persistent nephrotic syndrome with preserved renal function (20-30\%), and persistent nephrotic syndrome with progressive deterioration of renal function ( 30\%). ${ }^{15,16}$ Spontaneous remission is defined as the disappearance of the nephrotic syndrome with preservation of normal renal function, in the absence of any type of immunosuppressive treatment. Partial remission is defined as urinary protein excretion $<3.5 \mathrm{~g} / 24 \mathrm{~h}$ and a $50 \%$ or greater reduction from peak values, accompanied by an improvement or normalization of serum albumin and a stable renal function. ${ }^{38}$ Complete remission is defined as a urinary protein excretion $<0.3 \mathrm{~g} / 24 \mathrm{~h}$, accompanied by a normal serum albumin and a normal renal function. ${ }^{38}$ 
Spontaneous remission is a well-known characteristic of idiopathic membranous nephropathy. Patients with subnephrotic proteinuria and normal renal function, as well as women and patients with low levels of anti-PLA2R, have a higher chance of presenting SR. In a study by Polanco et $a l^{15}$ in more than 300 patients with PMN that were treated with conservative therapy, SR occurred in $32 \%$ of the cases at $14.7 \pm 11.4$ months after diagnosis. The decline of proteinuria was progressive rather than abrupt. An interesting finding was that although SR was more frequently observed in patients with lower levels of baseline proteinuria, up to $22 \%$ of patients with proteinuria $>12 \mathrm{~g} / 24 \mathrm{~h}$ also presented spontaneous remission. A high percentage of patients who developed SR received treatment with angiotensinconverting enzyme inhibitors (ACEI) or angiotensin receptor antagonists (ARBs). Other factors that significantly predicted SR were baseline renal function and proteinuria, and the reduction of baseline proteinuria by more than $50 \%$ during the first year. The long-term prognosis of patients with complete or partial spontaneous remission was excellent, with very few relapses (6\%) and a $100 \%$ renal survival. Pathophysiology of spontaneous remission is unknown to this day.

About $20-30 \%$ of cases present an aggressive clinical course with massive proteinuria and progressive deterioration of renal function during the first or second year from diagnosis. ${ }^{39,40} \mathrm{It}$ is important to differentiate these cases from patients with acute kidney injury secondary to reversible factors, such as the excessive use of diuretics, hypotension or volume depletion. Although some cases with an initial aggressive disease can present SR followed by stabilization or improvement of renal function, the vast majority has a poor prognosis in the absence of immunosuppressive treatment. ${ }^{39-41}$

The remaining patients $(\sim 30 \%)^{15,16}$ can present with persistent nephrotic syndrome without developing SR or deterioration of renal function. Although this scenario may persist for years, renal prognosis is poor if remission is not achieved. Moreover, persistent nephrotic syndrome increases the risk of atherosclerosis and thromboembolic events as a consequence of dysregulated lipid metabolism and dyslipidemia. ${ }^{42}$

\section{PROGNOSTIC MARKERS}

Patients with membranous nephropathy should be followed closely during the first 6 months since diagnosis, with careful monitoring (monthly o bimonthly) of renal function, proteinuria, and anti-PLA2R titers. Changes in these parameters will help the clinician to identify those patients more likely to develop spontaneous remission and those in whom prompt initiation of immunosuppression may be warranted.

The evolution of proteinuria and renal function during the first 6 months has been formulated mathematically by the Toronto Registry of Glomerulonephritis with the well-known Toronto Risk Score. ${ }^{43}$ This model has been validated in several countries with an accuracy of prediction of $85-90 \%$ to predict an unfavorable clinical course. According to this model, patients are stratified into the following categories: 1) low risk of progression (normal renal function, proteinuria $<4 \mathrm{~g} / 24 \mathrm{~h}$ ), 2) moderate risk of progression (normal renal function, proteinuria $4-8 \mathrm{~g} / 24 \mathrm{~h}$ ), and 3 ) high risk of progression (proteinuria $>8 \mathrm{~g} / 24 \mathrm{~h}$ regardless of renal function).
Some studies have shown that a high urinary excretion of IgG and some low-molecular weight proteins such as $\alpha-1$ microglobulin and $\beta 2$-microglobulin are excellent markers to predict the development of renal insufficiency, with a sensitivity and a specificity of $88 \%$ and $91 \%$, respectively. ${ }^{44,45}$ The potential advantage of these urinary markers is that monitoring would not be necessary since the initial measurement yields important predictive information.

In patients with PMN and positive anti-PLA2R, the major advance in terms of prognostic markers is undoubtedly the monitoring of antiPLA2R titers. High titers of anti-PLA2R at presentation suggest spontaneous remission will be unlikely, especially if increasing levels are observed over time. ${ }^{18,46}$ On the other hand, disappearance of antiPLA2R levels (immunologic remission), either spontaneous or induced by immunosuppressive therapy, precedes a clinical remission by a period of several months (up to 18 months in some cases). ${ }^{47-50} \mathrm{Anti}-$ body levels are also useful in the follow-up of patients who achieve remission as the reappearance of anti-PLA2R levels precede clinical relapse (by $\sim 3$ months). ${ }^{46,50}$ Likewise, those patients who still present detectable anti-PLA2R levels after immunosuppressive treatment are more likely to experience a clinical relapse. ${ }^{51}$ Moreover, persistence or reappearance of anti-PLA2R levels after kidney transplantation can also predict recurrence of the disease. ${ }^{52-54}$ In patients with de novo MN after a renal transplant, anti-PLA2R are invariably negative. ${ }^{55,56}$

At the present time, several PLA2R epitopes have been described (cysteine-rich domain [CysR], fibronectin type II domain, and eight distinct C-type lectin domains [CTLD1-8]). ${ }^{57} \mathrm{~A}$ recent study has proposed that epitope spreading at baseline is an indicator of poor prognosis and its presence should be considered in the decision for early therapeutic intervention. ${ }^{58}$

\section{TREATMENT}

The great advances made in the pathophysiologic field of PMN, accompanied by few but very relevant controlled clinical trials, have improved the therapeutic approach of these patients in recent years. It is now widely accepted that the type of treatment should be adapted or personalized to each patient, according to the clinical scenario (renal function, proteinuria) and the levels of anti-PLA2R (Figure 2). Although the optimal goal is to reach complete remission, the induction of partial remission is associated with a significantly superior renal survival compared to non-remission, and thus, it can be considered a satisfactory objective.

\section{Conservative strategy}

Scientific guidelines ${ }^{38}$ recommend starting immunosuppressive treatment only in those patients who maintain nephrotic proteinuria after an observation period of at least 6 months as long as proteinuria does not have a clear tendency to decrease during such period.

In all patients with $\mathrm{MN}$, optimal supportive care should be initiated at the time of diagnosis with the main goal of reducing proteinuria. Treatment should include ACEI/ARBs, statins for dyslipidemia, 


\section{Figure 2}

Proposed therapeutic strategy in membranous nephropathy.

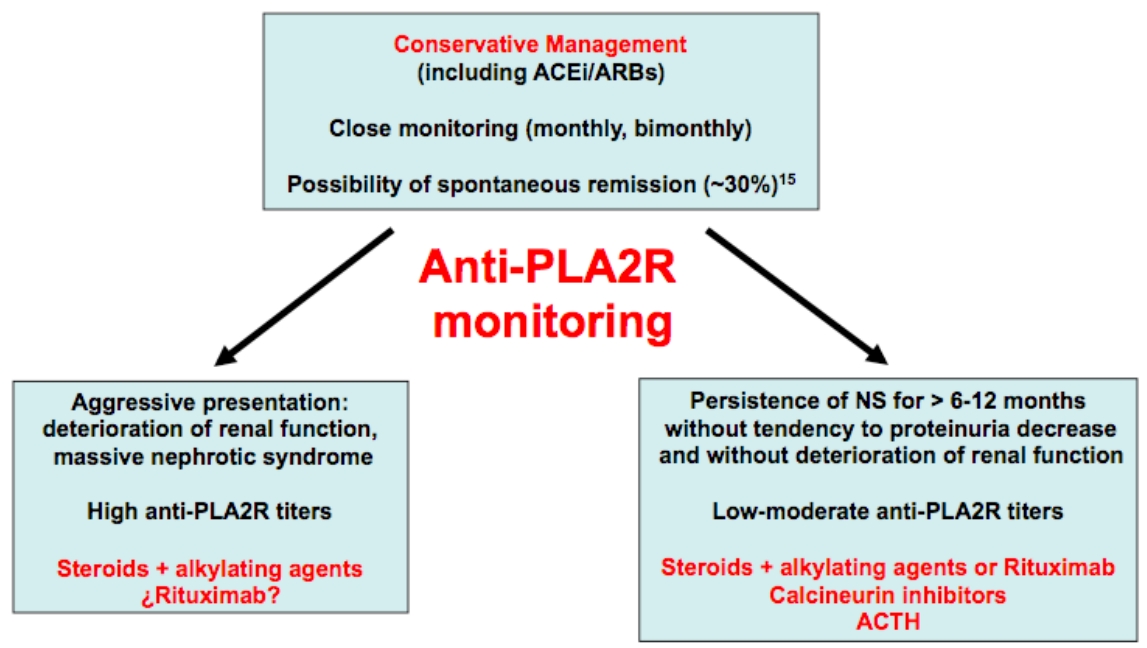

NS - nephrotic syndrome.

hypoproteic diet, salt restriction, and diuretics as needed. 2,6,33,59 Prophylactic anticoagulation should be considered if hypoalbuminemia is severe $(<2.5 \mathrm{~g} / \mathrm{dl})$ and other risk factors for thrombosis are present. ${ }^{60,61}$ Patients with progressive deterioration of renal function and those with severe, disabling, or life-threatening symptoms related to the nephrotic syndrome should be excluded from this observation period. ${ }^{38}$ In that cases, immunosuppressive treatment should be started unless there are specific contraindications. Increasing antiPLA2R titers over time should also guide towards initiation of immunosuppression. ${ }^{3}$ Immunosuppressive therapy in patients with persistently low glomerular filtration rate $(<30 \mathrm{ml} / \mathrm{min}$ per $1.73 \mathrm{~m} 2)$ or advanced interstitial fibrosis and tubular atrophy at biopsy is not recommended. 4,38

Treatment with ACEI decreases glomerular hypertension and improves glomerular barrier size selectivity. ${ }^{59,62}$ This results in reduction of proteinuria and improvement of hypoalbuminemia. Also, as previously mentioned, ACEI have been associated with the development of spontaneous remission. ${ }^{15}$ Nonetheless, its use should be cautious in patients without hypertension or with a compromised effective circulating volume.

\section{Immunosuppressive treatment}

Steroids and alkylating agents. Several randomized clinical trials have conclusively demonstrated the effectiveness of treatment with steroids and alkylating agents (cyclophosphamide and chlorambucil) when compared to conservative management. ${ }^{8-11,63}$ Cyclophosphamide is preferred over chlorambucil because of its better safety profile. However, cyclophosphamide can also cause severe adverse effects such as infections, cancer, and infertility. The modified Ponticelli regimen consist of 6 months of alternating pulse steroids and cyclophosphamide, achieving complete or partial remission in approximately $70-80 \%$ of the cases at $2-3$ years. ${ }^{9,11,63}$ Some authors have administered steroids and alkylating agents concomitantly rather than alternating, ${ }^{64}$ with no studies comparing which regimen is superior. Prospective studies have shown that monotherapy with steroids is

\section{$\underline{\text { Table } 2}$}

Summary of immunosuppressive treatment schemes for primary membranous nephropathy.

\begin{tabular}{|c|c|}
\hline Pharmacologic agent(s) & Dose scheme \\
\hline \multicolumn{2}{|r|}{ Alkylating agents ${ }^{8-11,38}$} \\
\hline Italian Ponticelli protocol & $\begin{array}{l}\text { Months 1, 3, 5: } 1 \mathrm{~g} / \mathrm{d} \text { IV MPDN x } 3 \mathrm{~d} \text {, followed by } \\
\text { oral PDN } 0.5 \mathrm{mg} / \mathrm{kg} / \mathrm{d} \text { × } 27 \mathrm{~d} \\
\text { Months 2, 4, 6: oral CHL } 0.2 \mathrm{mg} / \mathrm{kg} / \mathrm{d} \text { × } 30 \mathrm{~d}\end{array}$ \\
\hline Modified Ponticelli & $\begin{array}{l}\text { Months 1, 3, 5: } 1 \mathrm{~g} / \mathrm{d} \text { IV MPDN x } 3 \mathrm{~d} \text {, followed by } \\
\text { oral PDN } 0.5 \mathrm{mg} / \mathrm{kg} / \mathrm{d} \text { x } 27 \mathrm{~d} \\
\text { Months 2, 4, 6: oral CYC } 2-2.5 \mathrm{mg} / \mathrm{kg} / \mathrm{d} \text { × } 30 \mathrm{~d}\end{array}$ \\
\hline Dutch protocol & $\begin{array}{l}\text { Months } 1,3,5: 1 \mathrm{~g} / \mathrm{d} \text { IV MPDN x } 3 \mathrm{~d} \text {, followed by } \\
\text { oral PDN } 0.5-1 \mathrm{mg} / \mathrm{kg} / \mathrm{d} \text { × } 6 \text { months (then taper) } \\
\text { plus oral CYC } 1.5-2 \mathrm{mg} / \mathrm{kg} / \mathrm{d} \text { × } 12 \text { months }\end{array}$ \\
\hline \multicolumn{2}{|r|}{ Calcineurin inhibitors ${ }^{12,38,66,67}$} \\
\hline Tacrolimus & $\begin{array}{l}0.05-0.075 \mathrm{mg} / \mathrm{kg} / \mathrm{d} \text { x } 12 \text { months (through levels } \\
5-7 \mathrm{ng} / \mathrm{mL} \text { ), then taper over } 6 \text { months }+/ \text { - low dose } \\
\text { PDN }\end{array}$ \\
\hline Cyclosporine & $\begin{array}{l}3.5-5.0 \mathrm{mg} / \mathrm{kg} / \mathrm{d} \text { (through levels } 120-200 \mathrm{ng} / \mathrm{mL} \text { ) } x \\
12 \text { months, then taper over } 6 \text { months }+/ \text { low dose } \\
\text { PDN }\end{array}$ \\
\hline \multicolumn{2}{|r|}{ B cell-targeted $13,14,59,69$} \\
\hline Rituximab & $\begin{array}{l}375 \mathrm{mg} / \mathrm{m}^{2} \text { IV every week x } 4 \text { weeks } \\
1 \mathrm{~g} \mathrm{IV} \mathrm{x} 2 \text { (days } 1 \text { and } 15 \text { ) } \\
375 \mathrm{mg} / \mathrm{m}^{2} \text { IV single dose and follow B-cell counts }\end{array}$ \\
\hline \multicolumn{2}{|r|}{$\mathrm{ACTH}^{6,78,79}$} \\
\hline Tetracosactrin & $1 \mathrm{mg}$ IM twice weekly x 6-12 months \\
\hline Corticotropin & 80 U IM twice weekly x 6-12 months \\
\hline
\end{tabular}

IV - intravenous; IM - intramuscular; MPDN - methylprednisolone; PDN - prednisone; CHL - chlorambucil; CYC - cyclophosphamide. 
not effective. ${ }^{65} \mathrm{KDIGO}$ guidelines recommend the modified Ponticelli regimen as the preferred initial immunosuppressive therapy in patients resistant to a conservative strategy. ${ }^{38}$

Calcineurin inhibitors [CNIs]. Randomized prospective trials have also demonstrated the effectiveness of cyclosporine and tacrolimus in the treatment of $\mathrm{MN} .{ }^{12,66,67}$ In addition to its immunosuppressive effect, CNIs exert a direct antiproteinuric effect on the structure of the podocyte through its interaction with synaptopodin. ${ }^{68}$ Complete or partial remission has been observed in $70-85 \%$ of cases after $6-12$ months of therapy. ${ }^{12,66,67}$ In fact, the short-term efficacy of CNIs might be better than cyclophosphamide plus prednisone. ${ }^{67}$ Despite the high efficacy of CNIs in the management of $\mathrm{MN}$, a relapse rate of $\sim 40-50 \%$ has been reported after treatment discontinuation. ${ }^{12,66}$ On the other hand, the potential nephrotoxic effect of CNIs in the long term should be considered. Suggested initial doses of cyclosporine and tacrolimus are $3.5-5 \mathrm{mg} / \mathrm{kg} / \mathrm{d}$ and $0.05-0.075 \mathrm{mg} / \mathrm{kg} / \mathrm{d}$, respectively. ${ }^{12,67}$ Subsequent doses of CNIs should be adjusted to blood through levels (Table 2). The association of steroids in the case of tacrolimus is not mandatory. ${ }^{12}$ Recommended duration of treatment with CNIs is $12-18$ months and withdrawal should be gradual.
Rituximab. B-cell depletion is certainly the most promising therapy for membranous nephropathy. Rituximab has proven to be an effective agent in several recent studies, with the advantage of a superior safety profile compared to steroids and immunosuppressants. ${ }^{13,14,69} \mathrm{Com}$ plete or partial remission has been observed in 60-65\% of cases (up to $88 \%$ at 24 months), ${ }^{70}$ with a median time to remission of $\sim 7$ months. ${ }^{13,14}$ Lower anti-PLA2R antibody titer at baseline and immunologic remission (disappearance of anti-PLA2R levels) at 6 months are strong predictors of clinical remission. ${ }^{71}$ No clear correlation has been observed between B-cell counts and response or relapse rates. ${ }^{6}$ The optimal dose $\left(375 \mathrm{mg} / \mathrm{m}^{2} \times 4\right.$ or $\left.1 \mathrm{~g} \times 2\right)$ and the need of re-treatment remain incompletely defined, ${ }^{4}$ but lower doses $\left(375 \mathrm{mg} / \mathrm{m}^{2} \times 1\right)$ have proven to be poorly effective. ${ }^{72}$ MENTOR is a randomized controlled trial in which rituximab was compared to cyclosporine in patients with PMN. ${ }^{73}$ STARMEN is a randomized clinical trial that compared the efficacy of sequential tacrolimus-rituximab therapy to a modified Ponticelli protocol (Figure 3). ${ }^{74}$ This trial also evaluated the role of anti-PLA2R and other antibodies as markers of response to treatment and long-term prognosis. Results from the MENTOR and STARMEN trials are eagerly expected to better understand which patients benefit the most from rituximab therapy.

\section{Figure 3}

Schematic overview of the STARMEN trial.

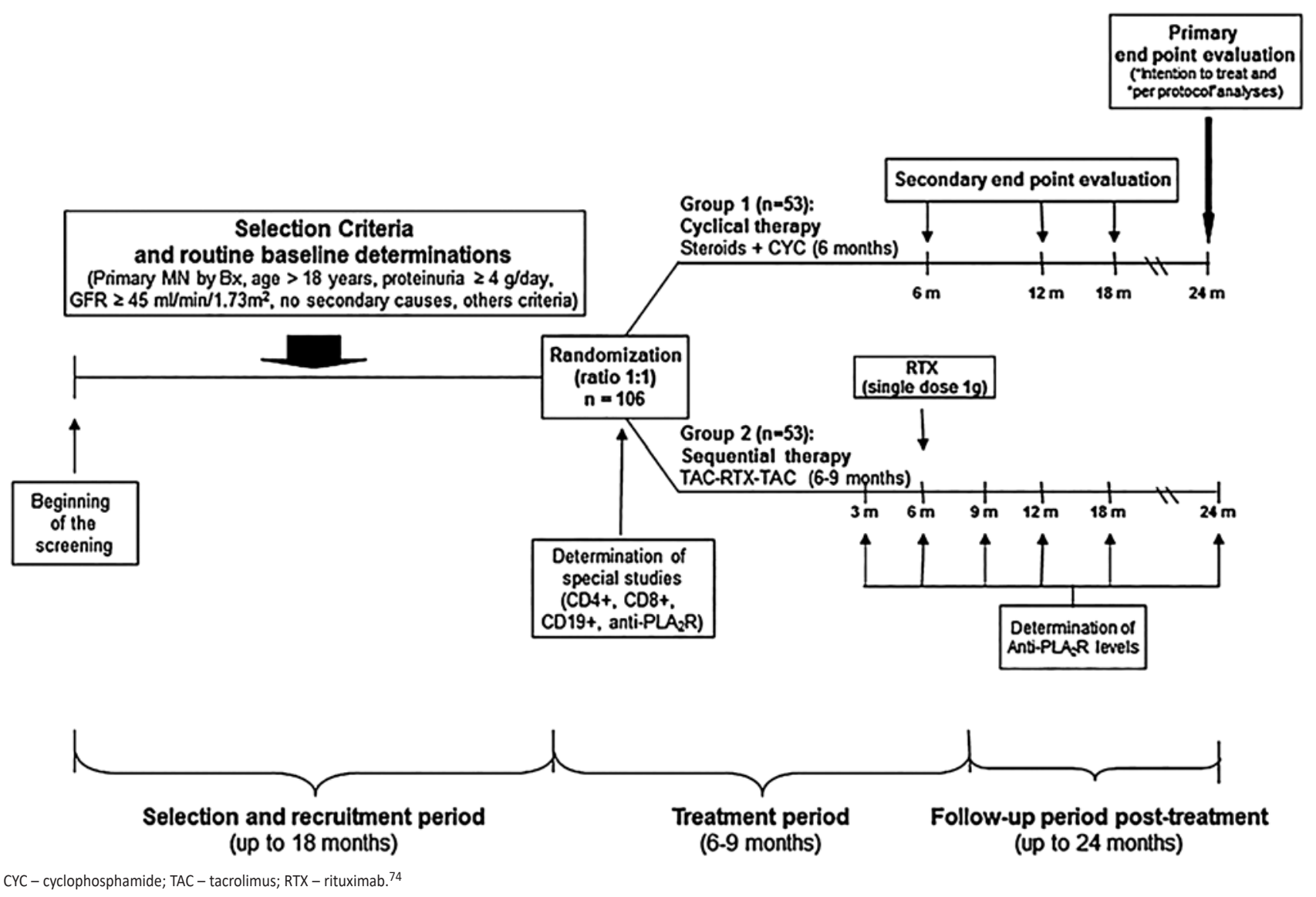


Mycophenolate Mofetil (MMF). The effectiveness of MMF in the treatment of membranous nephropathy has not been clearly demonstrated. In one randomized clinical trial, ${ }^{75}$ no differences were found in remission rates between MMF monotherapy and a conservative strategy. In another study, ${ }^{51}$ only $44 \%$ of the patients were in remission after 23 months of MMF plus prednisone treatment. However, better results with combined MMF + prednisone therapy have been reported in Asian patients in two randomized trials, ${ }^{76,77}$ with a remission rate similar to that observed with other immunosuppressants. More studies are needed to establish if MMF is useful in the treatment of $\mathrm{MN}$.

Adrenocorticotrophic hormone (ACTH). Subcutaneous or intramuscular administration of ACTH has shown considerable efficacy in patients with $\mathrm{MN}$ and nephrotic syndrome in retrospective case series ${ }^{78}$ and in one prospective pilot study. ${ }^{79}$ Remission rates up to $80 \%$ at 6 months have been reported, ${ }^{6,79}$ although one open label cohort study found that ACTH was less effective than cyclophosphamide in high risk patients. ${ }^{80}$ It should be noted that ACTH is very expensive and many of the available data of its efficacy and safety comes from small clinical trials (some of them observational). Therefore, the possible role of $\mathrm{ACTH}$ in the treatment of $\mathrm{MN}$ remains to be established.

New Therapies. Promising or alternative therapies include ofatumumab (third generation anti-CD20 monoclonal antibody), ${ }^{59}$ belimumab (monoclonal antibody that targets the soluble form of B lymphocyte stimulator [BLyS]), ${ }^{81}$ and bortezomib (proteasome inhibitor). ${ }^{82}$ One prospective randomized clinical trial (unpublished) failed to demonstrate the efficacy of eculizumab in $\mathrm{MN}$, although possibly as a result of underdosing. ${ }^{59,83}$

\section{MEMBRANOUS NEPHROPATHY AND KIDNEY TRANSPLANTATION}

The real incidence of recurrence after kidney transplantation (KT) is difficult to assess but it has been estimated to be around $30-44 \% .{ }^{59,84,85}$ Many patients are diagnosed incidentally during protocol biopsies while others present progressive proteinuria or even full nephrotic syndrome. ${ }^{86}$ Spontaneous remission is uncommon. In patients with PMN, the appearance of subepithelial deposits has been observed within days after KT.6,50,53 Nevertheless, clinical manifestations usually present between the second and third year after transplantation, or even later in some cases. ${ }^{86}$ Although some studies had reported that allograft survival in patients with recurrent $\mathrm{MN}$ is similar to those patients transplanted with other renal diseases, ${ }^{87}$ others had suggested a worse outcome..$^{50,53,88}$ The presence of anti-PLA2R antibodies at the time of $\mathrm{KT}$ is a risk factor for recurrent disease, especially if positivity persists during follow-up. ${ }^{53,89}$

De novo MN presents in approximately $2 \%$ of transplanted patients. ${ }^{90}$ Histologic pattern is practically indistinguishable from recurrent $\mathrm{MN}$. It has been associated with new-onset hepatitis $C$ virus infection, Alport syndrome, ureteral obstruction, renal infarction, recurrent IgA nephropathy, and graft rejection. ${ }^{88,91}$ Despite this, the pathogenic mechanisms involved in de novo MN are still speculative. While PMN is strongly associated with the presence of anti-PLA2R antibodies, patients with de novo MN have typically negative serology ${ }^{55}$ and staining on biopsy is almost always negative. ${ }^{92}$ As in recurrent $\mathrm{MN}$, whether de novo $\mathrm{MN}$ affects the outcome of kidney allografts is still controversial. ${ }^{93}$

Treatment with antiproteinuric agents should be initiated in all cases. The use of diuretics, statins, and anticoagulants is indicated on individual basis. Rituximab has been successfully used in cases of MN recurrence with complete and partial remission rates in up to $80 \%$ of cases. ${ }^{94,95}$ Similarly to treatment in native kidneys, the appropriate dose regime of rituximab has not been established. Prophylactic rituximab administration before $\mathrm{KT}$ has been attempted in some cases and may have been effective in preventing recurrence. Nonetheless, evidence in this sense is scarce. 6,59

\section{Disclosure of potential conflicts of interest: none declared.}

\section{References}

1. Ronco P, Debiec H. Pathophysiological advances in membranous nephropathy: time for a shift in patient's care. Lancet 2015; 385: 1983-92. DOI: 10.1016/S0140-6736(15)60731-0.

2. Cattran DC, Brenchley PE. Membranous nephropathy: integrating basic science into improved clinical management. Kidney Int. 2017 Mar;91(3):566-74. DOI: 10.1016/j.kint.2016.09.048.

3. De Vriese AS, Glassock RJ, Nath KA, Sethi S, Fervenza FC. A Proposal for a Serology-Based Approach to Membranous Nephropathy. J Am Soc Nephrol 28: 421-30, 2017. doi: 10.1681/ASN.2016070776

4. Ponticelli C, Glassock RJ. Glomerular diseases: membranous nephropathy--a modern view. Clin J Am Soc Nephrol. 2014 Mar;9(3):609-16. DOI: 10.2215/CJN.04160413.

5. Beck LH Jr, Bonegio RG, Lambeau G, Beck DM, Powell DW, Cummins TD, Klein JB, Salant DJ. M-type phospholipase A2 receptor as target antigen in idiopathic membranous nephropathy. $\mathrm{N}$ Engl J Med. 2009 Jul 2;361(1):11-21. DOI: 10.1056/NEJMoa0810457.

6. Couser WG. Primary Membranous Nephropathy. Clin J Am Soc Nephrol. 2017 Jun 7;12(6):983-97. DOI: $10.2215 /$ CJN.11761116

7. Tomas NM, Beck LH Jr, Meyer-Schwesinger C, Seitz-Polski B, Ma H, Zahner G, Dolla G, Hoxha E, Helmchen U, Dabert-Gay AS, Debayle D, Merchant M, Klein J, Salant DJ, Stahl RAK, Lambeau G. Thrombospondin type-1 domain-containing 7A in idiopathic membranous nephropathy. N Engl J Med. 2014 Dec 11;371(24):2277-87. DOI: 10.1056/NEJMoa1409354.

8. Ponticelli C, Zucchelli P, Passerini P, Cagnoli L, Cesana B, Pozzi C, Pasquali S, Imbasciati E, Grassi C, Redaelli B, Sasdelli M, Locatelli F. A randomized trial of methylprednisolone and chlorambucil in idiopathic membranous nephropathy. N Engl J Med. 1989 Jan 5;320(1):8-13. DOI: 10.1056/ NEJM198901053200102.

9. Ponticelli C, Zucchelli P, Passerini P, Cesana B, Locatelli F, Pasquali S, Sasdelli M, Redaelli B, Grassi C, Pozzi C, Bizzarri D, Banfi G. A 10-year follow-up of a randomized study with methylprednisolone and chlorambucil in membranous nephropathy. Kidney Int. 1995 Nov;48(5):1600-4. PMID: 8544420.

10. du Buf-Vereijken PW, Branten AJ, Wetzels JF; Membranous Nephropathy Study Group. Cytotoxic therapy for membranous nephropathy and renal insufficienacy: improved renal survival but high relapse rate. Nephrol Dial Transplant. 2004 May;19(5):1142-8. DOI: 10.1093/ndt/gfh036.

11. Jha V, Ganguli A, Saha TK, Kohli HS, Sud K, Gupta KL, Joshi K, Sakhuja V. A randomized, controlled trial of steroids and cyclophosphamide in adults with nephrotic syndrome caused by idiopathic membranous nephropathy. J Am Soc Nephrol. 2007 Jun;18(6):1899-904. DOI: 10.1681/ ASN.2007020166.

12. Praga M, Barrio V, Juárez GF, Luño J; Grupo Español de Estudio de la Nefropatía Membranosa. Tacrolimus monotherapy in membranous nephropathy: a randomized controlled trial. Kidney Int. 2007 May; 71(9):924-30. DOI: 10.1038/sj.ki.5002215.

13. Ruggenenti P, Cravedi P, Chianca A, Perna A, Ruggiero B, Gaspari F, Rambaldi A, Marasà M, Remuzzi G. Rituximab in idiopathic membranous nephropathy. J Am Soc Nephrol. 2012 Aug;23(8):1416-25. DOI: 10.1681/ASN.2012020181.

14. Dahan K, Debiec H, Plaisier E, Cachanado M, Rousseau A, Wakselman L, Michel PA, Mihout F, Dussol B, Matignon M, Mousson C, Simon T, Ronco P; GEMRITUX Study Group. Rituximab for Severe Membranous Nephropathy: A 6-Month Trial with Extended Follow-Up. J Am Soc Nephrol. 2017 Jan;28(1):348-58. DOI: 10.1681/ASN.2016040449.

15. Polanco N, Gutiérrez E, Covarsí A, Ariza F, Carreño A, Vigil A, Baltar J, Fernández-Fresnedo G, Martín C, Pons S, Lorenzo D, Bernis C, Arrizabalaga P, Fernández-Juárez G, Barrio V, Sierra M, Castellanos I, Espinosa M, Rivera F, Oliet A, Fernández-Vega F, Praga M; Grupo de Estudio de las Enfermedades Glomerulares de la Sociedad Española de Nefrología. Spontaneous Remission of Nephrotic Syndrome in Idiopathic Membranous Nephropathy. J Am Soc Nephrol 21: 697-704, 2010. DOI: 10.1681/ASN.2009080861

16. Fogo AB, Lusco MA, Najafian B, Alpers CE. AJKD Atlas of Renal Pathology: Membranous Nephropathy. Am J Kidney Dis. 2015 Sep;66(3):e15-7. DOI: 10.1053/j.ajkd.2015.07.006.

17. Debiec H, Guigonis V, Mougenot B, Decobert F, Haymann JP, Bensman A, Deschênes G, Ronco PM. Antenatal membranous glomerulonephritis due to anti-neutral endopeptidase antibodies. $\mathrm{N} \mathrm{Engl}$ J Med. 2002 Jun 27;346(26):2053-60. DOI: 10.1056/NEJMoa012895. 
18. McQuarrie EP. Anti-phospholipase A2 receptor antibodies in primary membranous nephropathy-10 key points. Nephrol Dial Transplant. 2018 Feb 1;33(2):212-3. DOI: 10.1093/ndt/gfx366.

19. Glassock RJ. Human idiopathic membranous nephropathy-a mystery solved? N Engl J Med. 2009 Jul 2;361(1):81-3. DOI: 10.1056/NEJMe0903343.

20. Salant DJ. In search of the elusive membranous nephropathy antigen. Nephron Physiol. 2009:112(1):p11-2. DOI: 10.1159/000212068.

21. Prunotto M, Carnevali ML, Candiano G, Murtas C, Bruschi M, Corradini E, Trivelli A, Magnasco A, Petretto A, Santucci L, Mattei S, Gatti R, Scolari F, Kador P, Allegri L, Ghiggeri GM. Autoimmunity in membranous nephropathy targets aldose reductase and SOD2. J Am Soc Nephrol. 2010 Mar;21(3):507-19. DOI: 10.1681/ASN.2008121259.

22. Debiec H, Lefeu F, Kemper MJ, Niaudet P, Deschênes G, Remuzzi G, Ulinski T, Ronco P. Earlychildhood membranous nephropathy due to cationic bovine serum albumin. N Engl J Med. 2011 Jun 2;364(22):2101-10. DOI: 10.1056/NEJMoa1013792.

23. Qin W, Beck LH Jr, Zeng C, Chen Z, Li S, Zuo K, Salant DJ, Liu Z. Anti-phospholipase A2 receptor antibody in membranous nephropathy. J Am Soc Nephrol. 2011 Jun;22(6):1137-43. DOI: 10.1681/ ASN.2010090967.

24. Schulze M1, Donadio JV Jr, Pruchno CJ, Baker PJ, Johnson RJ, Stahl RA, Watkins S, Martin DC, Wurzner R, Gotze $\mathrm{O}$, et al. Elevated urinary excretion of the C5b-9 complex in membranous nephropathy. Kidney Int. 1991 Sep;40(3):533-8. PMID: 1787650

25. Stanescu HC, Arcos-Burgos M, Medlar A, Bockenhauer D, Kottgen A, Dragomirescu L, Voinescu C, Patel N, Pearce K, Hubank M, Stephens HA, Laundy V, Padmanabhan S, Zawadzka A, Hofstra JM, Coenen MJ, den Heijer M, Kiemeney LA, Bacq-Daian D, Stengel B, Powis SH, Brenchley P, Feehally J, Rees AJ, Debiec H, Wetzels JF, Ronco P, Mathieson PW, Kleta R. Risk HLA-DQA1 and PLA(2 R1 alleles in idiopathic membranous nephropathy. N EngI J Med. 2011 Feb 17;364(7):616-26. DOI: 10.1056/NEJMoa1009742.

26. Gupta S, Köttgen A, Hoxha E, Brenchley P, Bockenhauer D, Stanescu HC, Kleta R. Genetics of membranous nephropathy. Nephrol Dial Transplant (2018) 33: 1493-502. DOI: 10.1093/ndt/ gfx296.

27. Jhaveri KD, Shah HH, Calderon K, Campenot ES, Radhakrishnan J. Glomerular diseases seen with cancer and chemotherapy: a narrative review. Kidney Int. 2013 Jul;84(1):34-44. DOI: 10.1038/ ki.2012.484.

28. Bacchetta J, Juillard L, Cochat P, Droz JP. Paraneoplastic glomerular diseases and malignancies. Crit Rev Oncol Hematol. 2009 Apr;70(1):39-58. DOI: 10.1016/j.critrevonc.2008.08.003.

29. Lefaucheur C1, Stengel B, Nochy D, Martel P, Hill GS, Jacquot C, Rossert J; GN-PROGRESS Study Group. Membranous nephropathy and cancer: Epidemiologic evidence and determinants of highrisk cancer association. Kidney Int. 2006 Oct;70(8):1510-7. DOI: 10.1038/sj.ki.5001790.

30. Glassock RJ. Diagnosis and natural course of membranous nephropathy. Semin Nephrol. 2003 Jul;23(4):324-32. PMID: 12923720.

31. Cattran DC. Idiopathic membranous glomerulonephritis. Kidney Int. 2001 May;59(5):1983-94. DOI: $10.1046 / j .1523-1755.2001 .0590051983 . x$

32. Fulladosa X, Praga M, Segarra A, Martínez Ara I. Glomerulonefritis membranosa. Nefrología 2007; 27 (Supl 2): 70-86.

33. Salant DJ, Cattran DC: Membranous nephropathy. Chapter 20. In: Comprehensive Clinical Nephrology, 5th Ed., edited by Floege J, Johnson RJ, Feehally J, St. Louis, MI, Saunders, an imprint of Elsevier Inc., 2015, pp 239-51

34. Praga M, Andres A, Hernandez E, Montoyo C, Mazuecos A, Campo C, Morales JM, Rodicio JL. Tubular dysfunction in nephrotic syndrome: incidence and prognostic implications. Nephrol Dial Transplant. 1991;6(10):683-8. PMID: 1754103.

35. Ronco $\mathrm{P}$, Debiec $\mathrm{H}$. Target antigens and nephritogenic antibodies in membranous nephropathy: Of rats and men. Semin Immunopathol. 2007;4:445-58. DOI: 10.1007/s00281-007-0091-2.

36. Schieppati A, Mosconi L, Perna A, Mecca G, Bertani T, Garattini S, Remuzzi G. Prognosis of untreated patients with idiopathic membranous nephropathy. N Engl J Med. 1993 Jul 8;329(2):859. DOI: 10.1056/NEJM199307083290203

37. Donadio JV Jr, Torres VE, Velosa JA, Wagoner RD, Holley KE, Okamura M, Ilstrup DM, Chu CP. Idiopathic membranous nephropathy: the natural history of untreated patients. Kidney Int. 1988 Mar;33(3):708-15. PMID: 3367560.

38. KDIGO Glomerulonephritis Work Group. KDIGO clinical practice guideline for glomerulonephritis. Kidney Int Suppl. 2012; 2: 139-274.

39. du Buf-Vereijken PW, Branten AJ, Wetzels JF. Idiopathic membranous nephropathy: outline and rationale of a treatment strategy. Am J Kidney Dis. 2005 Dec;46(6):1012-29. DOI: 10.1053/j. ajkd.2005.08.020.

40. Torres A, Domínguez-Gil B, Carreño A, Hernández E, Morales E, Segura J, González E, Praga M. Conservative versus immunosuppressive treatment of patients with idiopathic membranous nephropathy. Kidney Int. 2002 Jan;61(1):219-27. DOI: 10.1046/j.1523-1755.2002.00124.x.

41. Polanco N, Gutiérrez E, Rivera F, Castellanos I, Baltar J, Lorenzo D, Praga M; Grupo de Estudio de las Enfermedades Glomerulares de la Sociedad Española de Nefrología (GLOSEN). Spontaneous remission of nephrotic syndrome in membranous nephropathy with chronic renal impairment Nephrol Dial Transplant. 2012 Jan;27(1):231-4. DOI: 10.1093/ndt/gfr285.

42. Agrawal S, Zaritsky JJ, Fornoni A, Smoyer WE. Dyslipidaemia in nephrotic syndrome: mechanisms and treatment. Nat Rev Nephrol. 2018 Jan;14(1):57-70. DOI: 10.1038/nrneph.2017.155.

43. Cattran DC, Pei Y, Greenwood CM, Ponticelli C, Passerini P, Honkanen E. Validation of a predictive model of idiopathic membranous nephropathy: its clinical and research implications. Kidney Int. 1997 Mar;51(3):901-7. PMID: 9067928.

44. van den Brand JA, Hofstra JM, Wetzels JF. Low-molecular-weight proteins as prognostic markers in idiopathic membranous nephropathy. Clin J Am Soc Nephrol. 2011 Dec;6(12):2846-53. DOI: $10.2215 /$ CJN.04020411

45. Branten AJ, du Buf-Vereijken PW, Klasen IS, Bosch FH, Feith GW, Hollander DA, Wetzels JF. Urinary excretion of beta2-microglobulin and IgG predict prognosis in idiopathic membranous nephropathy: a validation study. J Am Soc Nephrol. 2005 Jan;16(1):169-74. DOI: 10.1681/ASN.2004040287.
46. Hofstra JM, Beck LH Jr, Beck DM, Wetzels JF, Salant DJ. Anti-phospholipase A2 receptor antibodies correlate with clinical status in idiopathic membranous nephropathy. Clin J Am Soc Nephrol. 2011 Jun;6(6):1286-91. DOI: 10.2215/CJN.07210810.

47. Hoxha E, Thiele I, Zahner G, Panzer U, Harendza S, Stahl RA. Phospholipase A2 receptor autoantibodies and clinical outcome in patients with primary membranous nephropathy. J Am Soc Nephrol. 2014 Jun;25(6):1357-66. DOI: 10.1681/ASN.2013040430.

48. Francis JM, Beck LH Jr, Salant DJ. Membranous Nephropathy: A Journey From Bench to Bedside. Am J Kidney Dis. 2016 Jul;68(1):138-47. DOI: 10.1053/j.ajkd.2016.01.030.

49. Beck LH Jr, Fervenza FC, Beck DM, Bonegio RG, Malik FA, Erickson SB, Cosio FG, Cattran DC, Salant DJ. Rituximab-induced depletion of anti-PLA2R autoantibodies predicts response in membranous nephropathy. J Am Soc Nephrol. 2011 Aug;22(8):1543-50. DOI: 10.1681/ASN.2010111125.

50. Ruggenenti P, Debiec H, Ruggiero B, Chianca A, Pellé T, Gaspari F, Suardi F, Gagliardini E, Orisio S, Benigni A, Ronco P, Remuzzi G. Anti-Phospholipase A2 Receptor Antibody Titer Predicts PostRituximab Outcome of Membranous Nephropathy. J Am Soc Nephrol. 2015 Oct;26(10):2545-58. DOI: $10.1681 /$ ASN.2014070640.

51. Bech AP, Hofstra JM, Brenchley PE, Wetzels JF. Association of anti-PLA2R antibodies with outcomes after immunosuppressive therapy in idiopathic membranous nephropathy. Clin J Am Soc Nephrol. 2014 Aug 7;9(8):1386-92. DOI: 10.2215/CJN.10471013.

52. Quintana LF, Blasco M, Seras M, Pérez NS, López-Hoyos M, Villarroel P, Rodrigo E, Viñas O, Ercilla G, Diekmann F, Gómez-Roman JJ, Fernandez-Fresnedo G, Oppenheimer F, Arias M, Campistol JM. Antiphospholipase A2 Receptor Antibody Levels Predict the Risk of Posttransplantation Recurrence of Membranous Nephropathy. Transplantation. 2015 Aug;99(8):1709-14. DOI: 10.1097/ TP.0000000000000630.

53. Kattah A, Ayalon R, Beck LH Jr, Sethi S, Sandor DG, Cosio FG, Gandhi MJ, Lorenz EC, Salant DJ, Fervenza FC. Anti-phospholipase A2 receptor antibodies in recurrent membranous nephropathy. Am J Transplant. 2015 May;15(5):1349-59. DOI: 10.1111/ajt.13133.

54. Seitz-Polski B, Payré C, Ambrosetti D, Albano L, Cassuto-Viguier E, Berguignat M, Jeribi A, Thouret MC, Bernard G, Benzaken S, Lambeau G, Esnault VL. Prediction of membranous nephropathy recurrence after transplantation by monitoring of anti-PLA2R1 (M-type phospholipase A2 receptor) autoantibodies: a case series of 15 patients. Nephrol Dial Transplant. 2014 Dec;29(12):233442. DOI: $10.1093 / \mathrm{ndt} / \mathrm{gfu} 252$

55. Debiec H, Martin L, Jouanneau C, Dautin G, Mesnard L, Rondeau E, Mousson C, Ronco P. Autoantibodies specific for the phospholipase $\mathrm{A} 2$ receptor in recurrent and de novo membranous nephropathy. Am J Transplant. 2011 Oct:11(10):2144-52. DOI: 10.1111/j.1600-6143.2011.03643.x.

56. Larsen CP, Walker PD. Phospholipase A2 receptor (PLA2R) staining is useful in the determination of de novo versus recurrent membranous glomerulopathy. Transplantation. 2013 May 27:95(10):1259-62. DOI: 10.1097/TP.0b013e31828a947b.

57. Ancian P, Lambeau G, Mattéi MG, Lazdunski M. The human 180-kDa receptor for secretory phospholipases A2. Molecular cloning, identification of a secreted soluble form, expression, and chromosomal localization. I Biol Chem. 1995 Apr 14:270(15):8963-70. PMID: 7721806.

58. Seitz-Polski B, Debiec H, Rousseau A, Dahan K, Zaghrini C, Payré C, Esnault VLM, Lambeau G, Ronco P. Phospholipase A2 Receptor 1 Epitope Spreading at Baseline Predicts Reduced Likelihood of Remission of Membranous Nephropathy. J Am Soc Nephrol. 2018 Feb;29(2):401-8. DOI: 10.1681/ASN.2017070734

59. Ruggenenti P, Fervenza FC, Remuzzi G. Treatment of membranous nephropathy: time for a paradigm shift. Nat Rev Nephrol. 2017 Sep;13(9):563-79. DOI: 10.1038/nrneph.2017.92.

60. Lee T, Biddle AK, Lionaki S, Derebail VK, Barbour SJ, Tannous S, Hladunewich MA, Hu Y, Poulton CJ, Mahoney SL, Charles Jennette J, Hogan SL, Falk RJ, Cattran DC, Reich HN, Nachman PH. Personalized prophylactic anticoagulation decision analysis in patients with membranous nephropathy. Kidney Int. 2014 Jun;85(6):1412-20. DOI: 10.1038/ki.2013.476.

61. Glassock RJ. Prophylactic anticoagulation in nephrotic syndrome: a clinical conundrum. J Am Soc Nephrol. 2007 Aug;18(8):2221-5. DOI: 10.1681/ASN.2006111300.

62. Ruggenenti P, Mosconi L, Vendramin G, Moriggi M, Remuzzi A, Sangalli F, Remuzzi G. ACE inhibition improves glomerular size selectivity in patients with idiopathic membranous nephropathy and persistent nephrotic syndrome. Am J Kidney Dis. 2000 Mar;35(3):381-91. PMID: 10692263.

63. Ponticelli C, Altieri P, Scolari F, Passerini P, Roccatello D, Cesana B, Melis P, Valzorio B, Sasdelli M, Pasquali S, Pozzi C, Piccoli G, Lupo A, Segagni S, Antonucci F, Dugo M, Minari M, Scalia A, Pedrini L, Pisano G, Grassi C, Farina M, Bellazzi R. A randomized study comparing methylprednisolone plus chlorambucil versus methylprednisolone plus cyclophosphamide in idiopathic membranous nephropathy. J Am Soc Nephrol. 1998 Mar;9(3):444-50. PMID: 9513907.

64. Torres A, Domínguez-Gil B, Carreño A, Hernández E, Morales E, Segura J, González E, Praga M. Conservative versus immunosuppressive treatment of patients with idiopathic membranous nephropathy. Kidney Int. 2002 Jan;61(1):219-27. DOI: 10.1046/j.1523-1755.2002.00124.x.

65. Cattran DC, Delmore T, Roscoe J, Cole E, Cardella C, Charron R, Ritchie S. A randomized controlled trial of prednisone in patients with idiopathic membranous nephropathy. N Engl J Med. 1989 Jan 26;320(4):210-5. DOI: 10.1056/NEJM198901263200403.

66. Cattran DC, Appel GB, Hebert LA, Hunsicker LG, Pohl MA, Hoy WE, Maxwell DR, Kunis CL; North America Nephrotic Syndrome Study Group. Cyclosporine in patients with steroid-resistant membranous nephropathy: a randomized trial. Kidney Int. 2001 Apr;59(4):1484-90. DOI: 10.1046/j.15231755.2001.0590041484.x.

67. Chen M, Li H, Li XY, Lu FM, Ni ZH, Xu FF, Li XW, Chen JH, Wang HY; Chinese Nephropathy Membranous Study Group. Tacrolimus combined with corticosteroids in treatment of nephrotic idiopathic membranous nephropathy: a multicenter randomized controlled trial. Am J Med Sci. 2010 Mar;339(3):233-8. DOI: 10.1097/MAJ.0b013e3181ca3a7d.

68. Mathieson PW. Proteinuria and immunity--an overstated relationship? N Engl J Med. 2008 Dec 4;359(23):2492-4. DOI: 10.1056/NEJMcibr0806881.

69. van den Brand JAJG, Ruggenenti P, Chianca A, Hofstra JM, Perna A, Ruggiero B, Wetzels JFM, Remuzzi G. Safety of Rituximab Compared with Steroids and Cyclophosphamide for Idiopathic Membranous Nephropathy. J Am Soc Nephrol. 2017 Sep;28(9):2729-37. DOI: 10.1681/ASN.2016091022. 
70. Beck LH Jr, Fervenza FC, Beck DM, Bonegio RG, Malik FA, Erickson SB, Cosio FG, Cattran DC, Salant DJ. Rituximab-induced depletion of anti-PLA2R autoantibodies predicts response in membranous nephropathy. J Am Soc Nephrol. 2011 Aug;22(8):1543-50. DOI: 10.1681/ASN.2010111125.

71. Ruggenenti P, Debiec H, Ruggiero B, Chianca A, Pellé T, Gaspari F, Suardi F, Gagliardini E, Orisio S, Benigni A, Ronco P, Remuzzi G. Anti-Phospholipase A2 Receptor Antibody Titer Predicts PostRituximab Outcome of Membranous Nephropathy. J Am Soc Nephrol. 2015 Oct;26(10):2545-58. DOI: 10.1681/ASN.2014070640

72. Moroni G, Depetri F, Del Vecchio L, Gallelli B, Raffiotta F, Giglio E, Brunini F, D’Amico M, Longhi S, Radice A, Messa P, Sinico RA. Low-dose rituximab is poorly effective in patients with primary membranous nephropathy. Nephrol Dial Transplant. 2017 Oct 1;32(10):1691-6. DOI: 10.1093/ ndt/gfw251.

73. US National Library of Medicine. ClinicalTrials.gov https://clinicaltrials.gov/ct2/show/NCT01180036 (2017).

74. Rojas-Rivera J, Fernández-Juárez G, Ortiz A, Hofstra J, Gesualdo L, Tesar V, Wetzels J, Segarra A, Egido J, Praga M. A European multicentre and open-label controlled randomized trial to evaluate the efficacy of Sequential treatment with TAcrolimus-Rituximab versus steroids plus cyclophosphamide in patients with primary MEmbranous Nephropathy: the STARMEN study. Clin Kidney J. 2015 Oct;8(5):503-10. DOI: 10.1093/ckj/sfv075.

75. Dussol B, Morange S, Burtey S, Indreies M, Cassuto E, Mourad G, Villar E, Pouteil-Noble C, Karaaslan $\mathrm{H}$, Sichez $\mathrm{H}$, Lasseur C, Delmas Y, Nogier MB, Fathallah M, Loundou A, Mayor V, Berland Y. Mycophenolate mofetil monotherapy in membranous nephropathy: a 1-year randomized controlled trial. Am J Kidney Dis. 2008 Oct;52(4):699-705. DOI: 10.1053/j.ajkd.2008.04.013.

76. Chan TM, Lin AW, Tang SC, Qian JQ, Lam MF, Ho YW, Tse KC, Chan KW, Lai KN, Tang CS. Prospective controlled study on mycophenolate mofetil and prednisolone in the treatment of membranous nephropathy with nephrotic syndrome. Nephrology (Carlton). 2007 Dec;12(6):576-81. DOI: 10.1111/j.1440-1797.2007.00822.x

77. Senthil Nayagam L, Ganguli A, Rathi M, Kohli HS, Gupta KL, Joshi K, Sakhuja V, Jha V. Mycophenolate mofetil or standard therapy for membranous nephropathy and focal segmental glomerulosclerosis: a pilot study. Nephrol Dial Transplant. 2008 Jun;23(6):1926-30. DOI: 10.1093/ndt/ gfm538.

78. Rauen T, Michaelis A, Floege J, Mertens PR. Case series of idiopathic membranous nephropathy with long-term beneficial effects of ACTH peptide 1-24. Clin Nephrol. 2009 Jun;71(6):637-42 PMID: 19473632

79. Ponticelli C, Passerini P, Salvadori M, Manno C, Viola BF, Pasquali S, Mandolfo S, Messa P. A randomized pilot trial comparing methylprednisolone plus a cytotoxic agent versus synthetic adrenocorticotropic hormone in idiopathic membranous nephropathy. Am J Kidney Dis. 2006 Feb-47(2):233-40. DOI: 10.1053/j.ajkd.2005.10.016.

80. van de Logt $A E$, Beerenhout $C H$, Brink HS, van de Kerkhof JJ, Wetzels JF, Hofstra JM. Synthetic ACTH in High Risk Patients with Idiopathic Membranous Nephropathy: A Prospective, Open Labe Cohort Study. PLoS One. 2015 Nov 12;10(11):e0142033. DOI: 10.1371/journal.pone.0142033.

81. Willcocks L, Barrett C, Brenchley P, Schmidt T, Gisbert S, Cai G, Savage C, Jones R. Effect of belimumab on proteinuria and anti-PLA2R autoantibody in idiopathic membranous nephropathy -6 months data. Nephrol. Dial. Transplant. 30, iii32-iii33 (2015). DOI:10.1093/ndt/gfv149.3.

82. Hartono C, Chung M, Kuo SF, Seshan SV, Muthukumar T. Bortezomib therapy for nephrotic syndrome due to idiopathic membranous nephropathy. J Nephrol. 2014 Feb;27(1):103-6. DOI: 10.1007/s40620-013-0028-x.
83. Evaluate. Alexion reports presentation of membranous nephritis clinical trials. http://www.evaluategroup.com/Universal/View.aspx?type=Story\&id=33783 (2002).

84. Lazowski P, Sablay LB, Glicklich D. Recurrent crescentic membranous nephropathy in two successive renal transplants: association with choroidal effusions and retinal detachment. Am J Nephrol. 1998;18(2):146-50. DOI: 10.1159/000013324.

85. Sprangers B, Lefkowitz GI, Cohen SD, Stokes MB, Valeri A, Appel GB, Kunis CL. Beneficial effect of rituximab in the treatment of recurrent idiopathic membranous nephropathy after kidney transplantation. Clin J Am Soc Nephrol. 2010 May;5(5):790-7. DOI: 10.2215/CJN.04120609.

86. Ponticelli C, Glassock RJ. Posttransplant recurrence of primary glomerulonephritis. Clin J Am Soc Nephrol. 2010 Dec;5(12):2363-72. DOI: 10.2215/CJN.06720810.

87. Briganti EM, Russ GR, McNeil JJ, Atkins RC, Chadban SJ. Risk of renal allograft loss from recurrent glomerulonephritis. N Engl J Med. 2002 Jul 11;347(2):103-9. DOI: 10.1056/NEJMoa013036.

88. Filippone EJ, Farber JL. Membranous nephropathy in the kidney allograft. Clin Transplant. 2016 Nov;30(11):1394-402. DOI: 10.1111/ctr.12847.

89. Seitz-Polski B, Payré C, Ambrosetti D, Albano L, Cassuto-Viguier E, Berguignat M, Jeribi A, Thouret MC, Bernard G, Benzaken S, Lambeau G, Esnault VL. Prediction of membranous nephropathy recurrence after transplantation by monitoring of anti-PLA2R1 (M-type phospholipase A2 receptor) autoantibodies: a case series of 15 patients. Nephrol Dial Transplant. 2014 Dec;29(12):233442. DOI: $10.1093 /$ ndt/gfu252.

90. Aline-Fardin A, Rifle G, Martin L, Justrabo E, Bour JB, D'Athis P, Tanter Y, Mousson C. Recurent and de novo membranous glomerulopathy after kidney transplantation. Transplant Proc. 2009 Mar;41(2):669-71. DOI: 10.1016/j.transproceed.2009.01.042.

91. Ponticelli C, Glassock RJ. De novo membranous nephropathy (MN) in kidney allografts. A peculia form of alloimmune disease? Transpl Int. 2012 Dec;25(12):1205-10. DOI: 10.1111/j.1432 2277.2012.01548.x.

92. Larsen CP, Walker PD. Phospholipase A2 receptor (PLA2R) staining is useful in the determination of de novo versus recurrent membranous glomerulopathy. Transplantation. 2013 May 27;95(10):1259-62. DOI: 10.1097/TP.0b013e31828a947b.

93. Ponticelli C, Moroni G, Glassock RJ. De novo glomerular diseases after renal transplantation. Clin J Am Soc Nephrol. 2014 Aug 7;9(8):1479-87. DOI: 10.2215/CJN.12571213.

94. Grupper A, Cornell LD, Fervenza FC, Beck LH Jr, Lorenz E, Cosio FG. Recurrent Membranous Nephropathy After Kidney Transplantation: Treatment and Long-Term Implications. Transplantation. 2016 Dec;100(12):2710-2716. DOI: 10.1097/TP.0000000000001056.

95. El-Zoghby ZM, Grande JP, Fraile MG, Norby SM, Fervenza FC, Cosio FG. Recurrent idiopathic membranous nephropathy: early diagnosis by protocol biopsies and treatment with anti-CD20 monoclonal antibodies. Am J Transplant. 2009 Dec;9(12):2800-7. DOI: 10.1111/j.1600-6143.2009.02851.x.

\section{Correspondence to:}

Manuel Praga, MD

Department of Nephrology. University Hospital 12 de Octubre.

Av. Córdoba km 5.400, 28041 Madrid, Spain.

E-mail: mpragat@senefro.org. 